\title{
The Fumarase Genes of Escherichia coli: Location of the fumB Gene and Discovery of a New Gene ( fumC)
}

\author{
By JOHN R. GUEST, * JOHN S. MILES, RUTH E. ROBERTS AND \\ SALLY A. WOODS \\ Department of Microbiology, Sheffield University, Sheffield S10 2TN, UK
}

(Received 16 May 1985)

\begin{abstract}
The fumB gene of Escherichia coli, which complements the fumarase deficiency of a fumA mutant when present in multiple copies, has been located at $93.5 \mathrm{~min}$ in the $E$. coli linkage map and its product has been identified as a polypeptide of $61 \mathrm{kDal}$. Four overlapping ColE $1-f u m B^{+}$ plasmids representing a continuous segment of $23 \cdot 3 \mathrm{~kb}$ of bacterial DNA have been isolated from the Clarke-Carbon $E$. coli gene bank and the location of the fumB gene relative to the restriction map and the adjacent mel operon has been defined. Hybridization studies have shown that the fumB gene is homologous to the fum $A$ gene, which complements the fum $A I$ mutation in single and multi-copy situations, and encodes an analogous $61 \mathrm{kDal}$ product formerly regarded as the $E$. coli fumarase. The hybridization studies also showed that the Bacillus subtilis fumarase gene ( $c i t G)$ is homologous to an independent gene, fumC (formerly $\mathrm{g} 48$ ), which lies adjacent to the fum $A$ gene at $35.5 \mathrm{~min}$ in the $E$. coli linkage map. The $\mathrm{N}$-terminal sequences of the cit $G$ and fum $C$ products exhibit a $51 \%$ identity over 88 residues. It is possible that the fum $C$ and cit $G$ genes are fumarase structural genes of $E$. coli and $B$. subtilis, and that the fum $A$ gene may encode a differentially-regulated fumarase or be a positive regulator gene which is essential for the expression of fum $C$ (but not $c i t G$ ). If so, the fumB gene may encode a related enzyme or activator that can replace the fum $A$ function when amplified.
\end{abstract}

\section{INTRODUCTION}

Fumarate hydratase or fumarase (EC 4.2.1.2) catalyses the interconversion of fumarate and L-malate. In facultative organisms such as Escherichia coli it functions in the citric acid cycle during aerobic respiratory metabolism, and during anaerobic glucose fermentation it participates in the reductive conversion of oxaloacetate to succinate. Consistent with this dual role, the synthesis of fumarase is only $40-60 \%$ repressed by anaerobiosis, and by glucose during aerobic growth (Gray et al., 1966). Studies with a mutant lacking fumarase have shown that the enzyme is essential for aerobic growth on fumarate and acetate, whereas growth on malate, glucose or complex media is only impaired by the deficiency (Guest \& Roberts, 1983). The fumarase mutation ( fumAl) does not prevent anaerobic growth on glucose minimal medium. However, this is not surprising since an anaerobic requirement for succinate (succinyl-CoA) is only imposed when isocitrate lyase and fumarate reductase are both blocked (Creaghan \& Guest, 1978). It would also appear that alternate pathways exist for the conversion of oxaloacetate to fumarate under anaerobic conditions. These involve either aspartate or malate as intermediates, and it may be significant that the enzymes of the former route, aspartate aminotransferase and aspartase, are induced anaerobically (Smith \& Neidhardt, 1983; Courtright \& Henning, 1970), whereas malate dehydrogenase and fumarase are repressed (Courtright \& Henning, 1970; Gray et al., 1966). It is also interesting that the fumAl mutation does not prevent anaerobic growth on glycerol plus $\mathrm{H}_{2}$ with malate as the source of the terminal oxidant (fumarate), which suggests that an alternative route from malate to fumarate may be operating. 

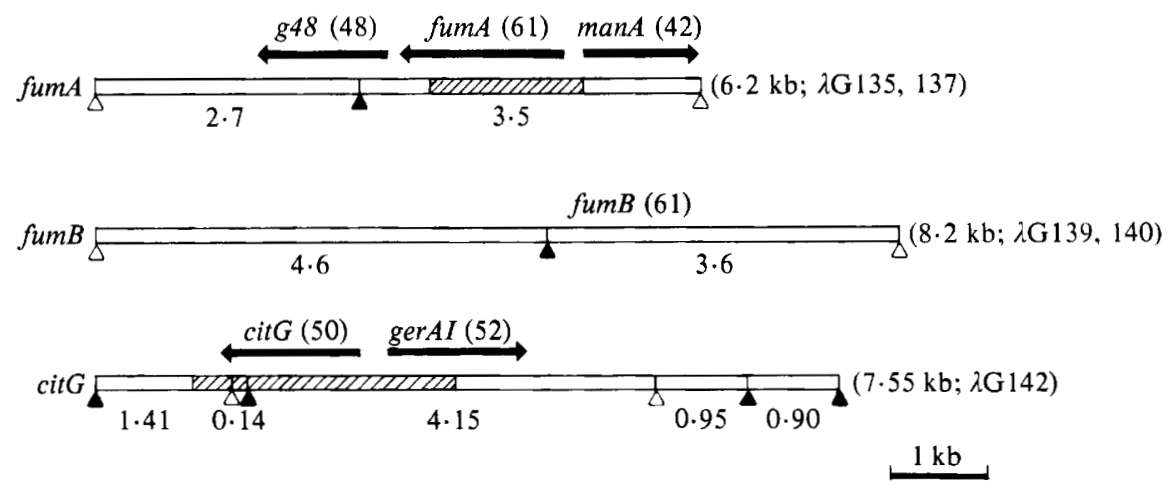

Fig. 1. Scale diagram showing the segments of $E$. coli and $B$. subtilis DNA cloned in $\lambda$ phages that complement the fumarase deficiency of the fumAl mutant of $E$. coli. The positions and polarities of known genes are indicated relative to the EcoRI $(\Delta)$ and HindIII $(\triangle)$ sites. The sizes of the gene products ( $\mathrm{kDal})$ and specific restriction fragments $(\mathrm{kb})$ are included. The shaded regions denote the segments of DNA cloned in the M13 phages that were used as hybridization probes.

Two fumarase genes, fum $A$ and $f u m B$, have been isolated in recombinant $\lambda$ phages by virtue of their ability to complement the fumarase deficiency of the fumA1 mutant (Guest \& Roberts, 1983). The fum $A$ gene encodes a $61 \mathrm{kDal}$ polypeptide which is expressed from a $6 \cdot 2 \mathrm{~kb}$ HindIII fragment that also contains the 6-phosphomannose isomerase gene (manA) and a gene ( $\mathrm{g} 48$ ) specifying an unidentified $48 \mathrm{kDal}$ product (Fig. 1). These genes are located at $35.5 \mathrm{~min}$ in the $E$. coli linkage map and the nucleotide sequences of the fum $A$ and $\operatorname{man} A$ genes and part of the unidentified gene $(g 48)$ have been defined (Miles \& Guest, $1984 a, b)$. The fumB gene is expressed from an $8 \cdot 2 \mathrm{~kb}$ HindIII fragment (Fig. 1), which encodes polypeptides of $61,56,43,33$ and possibly $52 \mathrm{kDal}$, and it differs from fum $A$ in being unable to complement the fumAl mutant except in high-copy situations such as transduction plaques or transformants with multi-copy plasmids. The fumAl mutant is also complemented by the Bacillus subtilis fumarase gene (citG) which has also been cloned and sequenced (Moir et al., 1984; Miles \& Guest, 1985). The citG gene encodes a $50 \mathrm{kDal}$ polypeptide which has no homology with the fum $A$ gene product.

The existence of two fum genes raises questions concerning their products and about the nature of the fumAl mutation. If it is assumed that fumA is the structural gene for the major fumarase then fumB could encode a minor or differentially-regulated fumarase. It could, for example, specify a fumarase that is only synthesized under anaerobic conditions or in high-copy situations where an aerobic repressor may be titrated by the fumB operators. It could also represent a vestigial or silent fumarase gene that is only expressed when coupled to a phage or plasmid promoter. The putative minor fumarase could resemble the unrelated $B$. subtilis fumarase ( $c i t G$ product). On the other hand, if there is only one fumarase in $E$. coli, the fumB gene could encode some other hydratase having a very weak fumarase activity (but sufficient to complement the fum $A$ lesion when amplified), or it could be a suppressor. The latter could have a direct effect on the fumAl mutation, or function indirectly by opening up an alternative metabolic route to bypass the need for fumarase.

This paper describes the properties of some ColE1-fumB $B^{+}$plasmids isolated from the ClarkeCarbon plasmid gene bank (Clarke \& Carbon, 1976) and the location of the fumB gene in the $93 \mathrm{rd}$ min of the $E$. coli linkage map. Evidence is presented that the fum $A$ and fumB genes encode homologous products $\left(M_{\mathrm{r}}=61000\right)$ which could either be fumarases, or regulatory proteins that activate the expression of a fumarase structural gene. Evidence is also presented for the existence of a new fumarase gene ( fum $C$, formerly designated $g 48$ ) that is adjacent to fum $A$ and encodes a protein that is analogous to the cit $G$-encoded fumarase of $B$. subtilis. 
Table 1. Strains of Escherichia coli K12

\begin{tabular}{|c|c|c|}
\hline Strain & Relevant genotype or phenotype & Source* or reference \\
\hline NK-1 & $\mathrm{F}^{-} ;$spoTI & E. Juni \\
\hline EJ1535 & $\operatorname{fum} A I$ & E. Juni; mutant of NK-1 \\
\hline JRG1331 & fumAl gyrA & $\mathrm{Nal}^{\mathrm{R}}$ derivative of $\mathrm{EJ} 1535$ \\
\hline JRG 1555 & fumAl gyrA recA srl:: $\operatorname{Tn} 10$ & Tet $^{\mathrm{R}} \mathrm{Rec}^{-}$transductant of JRG1331 \\
\hline ED8641 & Met $^{-}$Trp $^{-}$Aux ${ }^{-}$supE hsdR recA56 & N. E. Murray \\
\hline GM242 & $\operatorname{dam}-3 \operatorname{rec} A I$ & M. Marinus \\
\hline AB2480 & uvrA6 recA13 & P. J. Emmerson \\
\hline $\mathrm{C} 600$ & $\lambda^{\mathrm{S}}$ & N. E. Murray \\
\hline PL2024 & $\operatorname{rps} L \lambda^{\mathrm{s}}$ & Lambden \& Guest (1976) \\
\hline F500/GMS724 & F500; rpsL700 $\lambda^{\mathrm{S}}$ & CGSC 5505 \\
\hline $\mathrm{H}$ & Hfr (97 min); thi-l & W. Hayes \\
\hline KL14 & $\mathrm{Hfr}(67 \mathrm{~min}) ;$ thi-l & CGSC 4294 \\
\hline KLl6 & Hfr (62 min); thi-I & CGSC 4245 \\
\hline CH931 & $\mathrm{Hfr}(97 \mathrm{~min}) ;$ lys $A$ polAl & C. W. Hill; Greener \& Hill (1980) \\
\hline BW360 & polAl zig-219::Tn 10 & W. Wickner; Silver \& Wickner (1983) \\
\hline JRG1595 & Hfr $(67 \mathrm{~min}) ;$ thi-1 polA1 zig- $219:: \operatorname{Tn} 10$ & Tet $^{\mathrm{R}}$ PolA $^{-}$transductant of $\mathrm{KL14}$ \\
\hline X478G3 & $\mathrm{F}^{-} ;$leu-6 proC purE $\mathrm{Trp}^{-}$thi-I & Herbert \& Guest (1968) \\
\hline AB2294 & $\begin{array}{l}\mathrm{F}^{-} ; \text {proA } 2 \text { trp-3 his-4 ilvD145 metE46 thi-1 } \\
\text { malA1 rpsL } 8 \text { or } 9 \lambda^{-} \lambda^{\mathrm{R}}\end{array}$ & CGSC 2294 \\
\hline $\mathrm{JC} 1552$ & 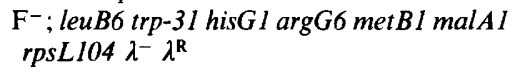 & CGSC 4273 \\
\hline AB2495 & $\begin{array}{l}\mathrm{F}^{-} ; \text {thr-1 leuB6 proA2 trp-35 hisG4 thy A20 } \\
\text { argE3 thi-1 rpsL31 }\end{array}$ & CGSC 2495 \\
\hline RM1003 & purA & Spencer \& Guest (1973) \\
\hline PA2004 & pyrB thr-I leu-6 his-I & Spencer \& Guest (1973) \\
\hline Q11 & $\mathrm{Fdp}^{-}$ & Spencer \& Guest (1973) \\
\hline JRG780 & frdAII $\operatorname{trp} A$ & Cole \& Guest (1980) \\
\hline JRG820 & mel-1 gltC8 (P1) & Formerly Ymel/G; Spencer et al. (1976) \\
\hline M2508 & melA7 metBI & CGSC 4926 \\
\hline M1900 & melB4 metBl & CGSC 5934 \\
\hline JA200 & $\mathrm{F}^{+} ;$thr-1 leuB6 trpE5 thi-1 recA56 & B. J. Bachmann \\
\hline
\end{tabular}

* E. Juni, Department of Microbiology, University of Michigan, Mich., USA; N. E. Murray, Department of Molecular Biology, University of Edinburgh, UK; M. Marinus, Department of Pharmacology, Rutgers Medical School, NJ, USA; P. J. Emmerson, Department of Biochemistry, University of Newcastle, UK; CGSC (E. coli Genetic Stock Center; B. J. Bachmann, Curator) Yale University, New Haven, Conn., USA; W. Hayes, Department of Botany, Australian National University, Canberra, Australia; C. W. Hill, Department of Biological Chemistry and Cancer Research Center, Pennsylvania State University, Hershey, Pa., USA; W. Wickner, Molecular Biology Institute and Department of Biological Chemistry, University of California, Los Angeles, Calif., USA.

\section{METHODS}

Bacterial strains. The strains of $E$. coli used are listed in Table 1. The routine transformation host was ED8641, but GM242 was used when $B c l I$-susceptible DNA was required. Strain $C 600$ was used for assaying $\lambda$ phages except following zygotic induction when Str $^{R}$ (PL2024) or Str ${ }^{\mathrm{R}}$ F-prime (F500) strains were used. Phages P1 kc and P1 virl were assayed with Shigella dysenteriae. The map positions of the markers used in the linkage studies and the points of origin for the Hfr strains are indicated in Fig. 5. The polA derivative of KL14, JRG1595, was prepared by contransducing the polAl mutation with a closely-linked Tn 10 insertion using a Plvirl lysate of BW360. Tet ${ }^{R}$ transductants were screened for: sensitivity to methyl methanesulphonate (PolA ${ }^{-}$), using $\mathrm{L}$ agar containing methyl methanesulphonate $(0.08 \%, \mathrm{v} / \mathrm{v})$; retention of $\mathrm{Hfr}$ activity, by cross-streak conjugation with $\mathrm{JC1} 552$; and P1-sensitivity.

Phages and plasmids. Several $\lambda$ transducing phages containing the fum $A$ and fumB regions of $E$. coli were used: $\lambda \mathrm{Gl} 35(\lambda$ fum $A)$ and $\lambda \mathrm{G} 139-140(\lambda$ fumB $), \Delta s r I \lambda 1-2$ shn $\lambda 3::$ fum $_{\text {att }}{ }^{+}$int $^{+}$imm $^{21}$ nin 5 shn $\lambda 6^{\circ}$; and $\lambda \mathrm{G} 137$ ( $\lambda$ fumA) and $\lambda \mathrm{G} 141(\lambda$ fumB $), \Delta s r I \lambda 1-2 \operatorname{shn} \lambda 3::$ fum $\Delta\left(\right.$ att-red) $\mathrm{imm}^{21} \operatorname{nin} 5 \operatorname{shn} \lambda 6^{\circ}$ (Guest \& Roberts, 1983). A phage containing the citG region of $B$. subtilis was also used: $\lambda G 142$ ( $\lambda$ citG), $\Delta s r I \lambda 1-3:: c i t G c I 857$ srI $I 4^{\circ}$ (Moir et al., 1984). Other phages, $\lambda b 2 c \mathrm{imm}^{21}$ and $\lambda v i r$, were used in lysogen selection and for testing immunity and sensitivity.

Plasmid pGS56 is a derivative of pBR322 that contains the fumB region ( $8.2 \mathrm{~kb}$ HindIII fragment) and retains the $\mathrm{Amp}^{\mathrm{R}}$ and $\mathrm{Tet}^{\mathrm{R}}$ markers (Guest \& Roberts, 1983). A culture containing samples of all the clones in the ColE1E. coli plasmid gene bank of Clarke \& Carbon (1976) was kindly provided by Dr S. T. Cole (Pasteur Institute, 
Paris, France), and strains containing specific plasmids (pLC4-5, pLC17-38 and pLC25-33) were obtained from Dr B. J. Bachmann (Yale University, New Haven, Conn., USA). The host strain for the ColE1-hybrid plasmids was JA200.

Media. The rich medium for subculturing was L broth, or LG broth for citric acid cycle mutants, and BBL medium was used for $\lambda$ phage assays (Guest, 1981). Media were solidified with Difco Bacto agar at 10 or $15 \mathrm{~g} \mathrm{l}^{-1}$ for plates or 6.5 $\mathrm{g} \mathrm{l}^{-1}$ for top layers. Minimal medium E (Vogel \& Bonner, 1956) was used with carbon sources, glucose $(11 \mathrm{mM})$, melibiose $(5 \mathrm{mM})$, maltose $(5 \mathrm{mM})$, glycerol $(40 \mathrm{mM})$, potassium fumarate $(40 \mathrm{mM})$, and other supplements, L-amino acids $\left(30 \mu \mathrm{g} \mathrm{ml}^{-1}\right)$, adenine $\left(35 \mu \mathrm{g} \mathrm{ml}^{-1}\right)$, uracil $\left(35 \mu \mathrm{g} \mathrm{ml}^{-1}\right)$, thymine $\left(50 \mu \mathrm{g} \mathrm{ml}^{-1}\right)$, vitamin $B_{1}\left(5 \mu \mathrm{g} \mathrm{ml}^{-1}\right)$, as required for different nutritional tests and genetic selections. The antibiotic supplements were $\left(\mu \mathrm{g} \mathrm{ml}^{-1}\right)$ : ampicillin (50-100); tetracycline (15); streptomycin (200) and nalidixic acid (10). The glycerol plus fumarate medium (GF) was used for $\mathrm{Frd}^{+}$selection using an atmosphere of $\mathrm{H}_{2}+\mathrm{CO}_{2}(5 \%$, v/v) according to Lambden \& Guest (1976).

Genetic methods. (a) Transformation with plasmid DNA was done by the method of Lederberg \& Cohen (1974) except that the first wash with $\mathrm{CaCl}_{2}$ was omitted.

(b) Transduction with phage Pl was done by the method of Spencer et al. (1976) using an m.o.i. of 2. For strain construction the m.o.i. was reduced to 0.01 and EGTA $(2.5 \mathrm{mM})$ was added, before plating, to chelate $\mathrm{Ca}^{2+}$ ions and so limit superinfection with free phage particles.

(c) Conjugation. $\mathrm{F}^{+}$-mediated ColE1 transfer from a culture containing representatives of all the clones in the Clarke-Carbon gene bank to JRG1331 (F $\mathrm{F}^{-}$; fumAl gyrA) was done by mixing equal volumes $(0.5 \mathrm{ml})$ of exponential cultures in a total of $2.5 \mathrm{ml} \mathrm{L}$ broth for $4 \mathrm{~h}$ at $37^{\circ} \mathrm{C}$. Fum ${ }^{+} \mathrm{Nal}^{\mathrm{R}}$ exconjugants were selected on fumarate minimal medium plus nalidixic acid $\left(10 \mu \mathrm{g} \mathrm{ml}^{-1}\right)$, and then purified by single colony isolation on the same medium before examination for the presence of ColEl hybrid plasmids. Interrupted mating experiments for analysing zygotic induction and for time of entry mapping were done according to Jacob \& Wollman (1956). Mating mixtures were sampled at $10 \mathrm{~min}$ intervals for up to $100 \mathrm{~min}$, separated by vortex mixing for $1 \mathrm{~min}$ in $\mathrm{L}$ broth plus streptomycin, and dilutions were plated on appropriate media (with or without an indicator organism) to assay phage-generating merozygotes and different recombinant classes. Conjugational linkage analysis was done by the method of Herbert \& Guest (1968). Donor and recipient cultures were mated for 100 to $120 \mathrm{~min}$, vortexed for $1 \mathrm{~min}$, and dilutions were plated immediately on a variety of selective media to assess the gradients of marker transmission, except in the case of $A m p^{R}$, where the mixtures were diluted 5-fold and incubated for $1 \mathrm{~h}$ at $37^{\circ} \mathrm{C}$ before plating. Recombinants were purified on the selective medium before testing for inheritance of nonselective markers by replica-plating. Cross-streak tests for donor activity were done on solid media according to Lambden \& Guest (1976).

Isolation and manipulation of DNA. The methods for isolating phage and plasmid DNA have been described previously, as have the methods for restriction enzyme digestion, agarose gel electrophoresis and DNA ligation (Guest et al., 1983; Moir et al., 1984). Small scale plasmid preparations were used for routine screening and transformation (Birnboim \& Doly, 1979). Fragments of DNA were isolated either by electrophoresis in low melting point agarose (BRL) and phenol extraction according to the manufacturer's instructions, or with DEAEcellulose paper (Dretzen et al., 1981) for standard agarose.

'Maxicell' procedures. Polypeptides expressed by plasmid-encoded genes were labelled with L- ${ }^{35}$ S $]$ methionine by the 'maxicell' technique of Sancar et al. (1979) by using AB2480 derivatives as detailed by Shaw \& Guest (1982).

DNA labelling and hybridization methods. Single-stranded M13 DNA containing segments of bacterial DNA was isolated by the method of Sanger et al. (1980) and labelled with $\left[\alpha^{-32} \mathrm{P}\right] \mathrm{dATP}$ to $>10^{6} \mathrm{c}$.p.m. per $\mu \mathrm{g}$ of DNA by synthesizing a complementary M13 strand with a hybridization probe primer according to Hu \& Messing (1982). Restriction fragments from $\lambda$ fum and $\lambda$ citG DNA $(0 \cdot 2 \mu \mathrm{g})$ were separated in agarose gels and transferred overnight to nitrocellulose filters (Southern, 1975), or total genomic DNA samples $(4 \mu \mathrm{g})$ were applied as spots directly to the filters. The filters were baked at $80^{\circ} \mathrm{C}$ for $2 \mathrm{~h}$ in vacuo, and then treated according to the prehybridization and hybridization procedures of Maniatis et al. (1982). Hybridization was done with $10^{5}$ to $10^{6} \mathrm{c} . \mathrm{p} . \mathrm{m}$. of ${ }^{32} \mathrm{P}$-labelled probe per filter in $10 \mathrm{ml}$ of a $6 \times \mathrm{SSC}$ hybridization solution $(1 \times \mathrm{SSC}$ is $0.15 \mathrm{M}-\mathrm{NaCl}, 0 \cdot 15 \mathrm{M}$-trisodium citrate, $\mathrm{pH} 7 \cdot 0$ ) at $65^{\circ} \mathrm{C}$ for $18 \mathrm{~h}$. The filters were subsequently washed with $4 \times \mathrm{SSC}$ (low stringency) and $0 \cdot 1 \times \operatorname{SSC}($ high stringency) solutions at the same temperature, and then autoradiographed with a fluorescent screen.

Materials. Restriction enzymes, $\mathrm{T}_{4}$ DNA ligase, DNA polymerase (Klenow fragment) and hybridization probe primer were purchased from BRL, New England Biolabs, Boehringer and Gibco-PL. The radiochemicals, $\mathrm{L}-\left[{ }^{35} \mathrm{~S}\right]$ methionine $\left(0.8 \mathrm{Ci} \mathrm{mol}^{-1} ; 30 \mathrm{GBq} \mathrm{mol}^{-1}\right)$ and $2^{\prime}$-deoxyadenosine $5^{\prime}-\left[\alpha^{-32} \mathrm{P}\right]$ triphosphate $\left(3 \mathrm{Ci} \mathrm{mol}^{-1}\right.$; $110 \mathrm{GBq} \mathrm{mol}^{-1}$ ) were from Amersham.

\section{RESULTS}

\section{Isolation of ColE1-fum ${ }^{+}$plasmids}

A culture containing representatives of all the clones in the Clarke-Carbon $E$. coli gene bank was screened by $\mathrm{F}^{+}$-mediated conjugation for complementation of the fumarase lesion of strain 


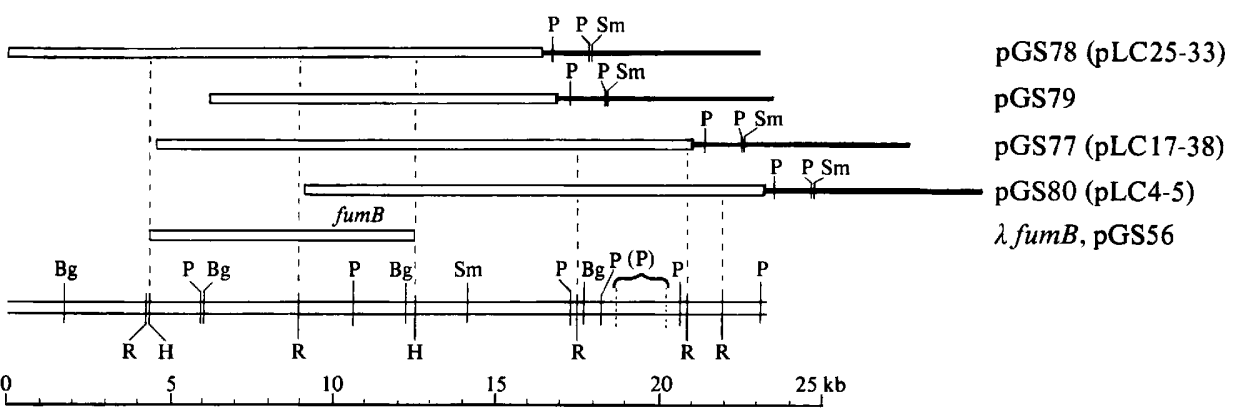

Fig. 2. Restriction maps of the ColE $1-$ fum $^{+}$plasmids, drawn to scale in a linearized form and showing the bacterial DNA (open bars) and ColEI DNA (thick lines). The segment of bacterial DNA found in the $\lambda$ fumB phages and subcloned into plasmid pGS56 is indicated, as is the common segment (marked fum $B$ ) presumed to contain the fumB gene. The pLC plasmids, which are probably identical to three of the pGS isolates, are also indicated. All of the sites were unambiguously assigned except the Pst I site denoted (P). The restriction sites are abbreviated as follows: Bg, BglII; H, HindIII ; P, PstI ; R, Eco RI ; Sm, SmaI.

JRG1331 ( fumA1 gyrA). Fum ${ }^{+}$exconjugants were selected on fumarate minimal medium containing nalidixic acid $\left(10 \mu \mathrm{g} \mathrm{ml}^{-1}\right)$ to counterselect the donors. The plasmid contents of ten independent $\mathrm{Fum}^{+}$colonies were examined and four different types of ColE1-fum ${ }^{+}$plasmid were detected: pGS77 $(23.2 \mathrm{~kb})$, pGS78 $(23.0 \mathrm{~kb})$, pGS79 $(17.3 \mathrm{~kb})$, and pGS80 $(20.8 \mathrm{~kb})$. Restriction analysis (Fig. 2) with combinations of five restriction endonucleases revealed the presence of four overlapping inserts, which also overlap the $8.2 \mathrm{~kb}$ HindIII fragment that had been isolated previously in several $\lambda \mathrm{fumB}$ transducing phages and was later subcloned in the pBR322-fumB $B^{+}$plasmid, pGS56 (Guest \& Roberts, 1983). The corresponding segments of bacterial DNA $(10.7$ to $16.6 \mathrm{~kb})$ were clearly derived from a $23.3 \mathrm{~kb}$ region of the bacterial chromosome containing the fumB gene, and the results indicated that fumB is expressed from a common $3.4 \mathrm{~kb}$ region (Fig. 2). It is not clear why no ColE1-fum $A^{+}$plasmids were recovered, but an exhaustive search was not made.

\section{Identification of the fumB gene product}

In previous studies with two $\lambda$ fumB phages ( $\lambda$ G139 and $\lambda$ G140) and with pGS56, evidence was obtained that the $8.2 \mathrm{~kb}$ HindIII fragment directed the synthesis of polypeptides of 61,56 , 43,33 and possibly $52 \mathrm{kDal}$ (Guest \& Roberts, 1983). The polarities of expression of the 61 and $43 \mathrm{kDal}$ products were defined as leftward relative to the restriction map shown in Fig. 2 . A restriction map of the fumB region of pGS56 is illustrated in Fig. 3. No sites were detected for ClaI, KpnI, SalI, SmaI, SstI or XhoI. In order to define the precise location of the fumB gene and to identify its product, a series of pBR322 derivatives containing sub-segments of the fumB region were constructed (Fig. 3). Plasmids pGS93, pGS100 and pGS142 are deletion derivatives of pGS56, obtained by re-ligating the products of BamHI, EcoRI and SphI digestion, respectively. Plasmid pGS143 is likewise a $B c / I-B a m H I$ deletion derivative of pGS93. Plasmids pGS144 and pGS145 were obtained by recloning the $2.4 \mathrm{~kb} S p h \mathrm{I}-B g / \mathrm{II}$ (pGS56) and $1.85 \mathrm{~kb}$ EcoRI-PstI (pGS93) fragments into pBR322. In each case the reconstructed plasmids were recovered as $\mathrm{Amp}^{\mathrm{R}} \mathrm{Tet}^{\mathrm{S}}$ or $\mathrm{Tet}^{\mathrm{R}} \mathrm{Amp}^{\mathrm{S}}$ transformants of ED8641 and their structures were confirmed by restriction analysis. Their ability to complement the fumAl lesion was then tested non-selectively by first isolating $\mathrm{Amp}^{\mathrm{R}}$ transformants of JRG1555 (or $\mathrm{Tet}^{\mathrm{R}}$ transformants of EJ1535) and then screening for the Fum ${ }^{+/-}$phenotype. The results are shown in Fig. 3, and it is apparent that the smallest fragment from which an active fumB product can be expressed is the $2.4 \mathrm{~kb} S p h \mathrm{I}-B g / \mathrm{II}$ segment of pGS144. Deletions extending as far as the $B c l$ site (in pGS143) or the $P$ stI site (in pGS145) inactivate the fum $B$ function and so define an essential $0.85 \mathrm{~kb}$ segment of the fumB gene. This location is consistent with the results obtained with the ColE1 plasmids. 


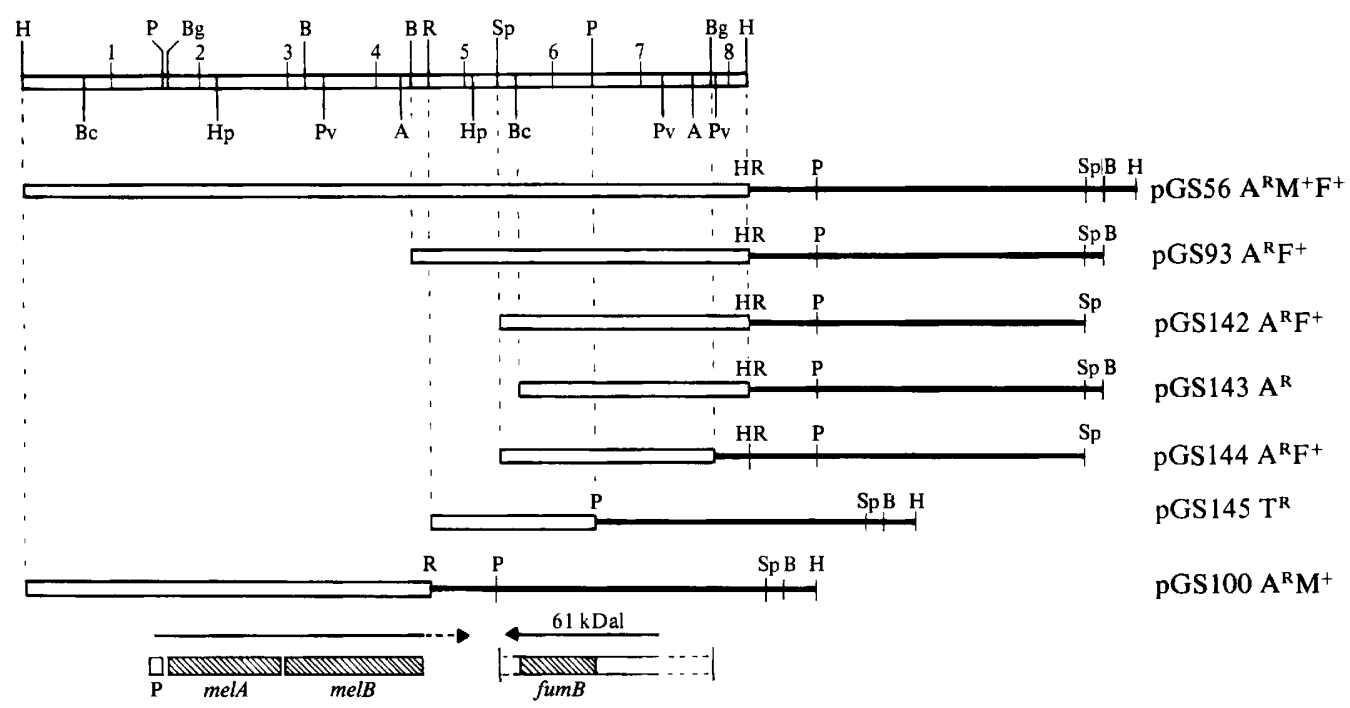

Fig. 3. Physical maps of derivatives of plasmid pBR322 containing different segments of the $8.2 \mathrm{~kb}$ fum $B$ region. The phenotypic characteristics conferred by the plasmids are abbreviated: $\mathrm{F}^{+}, \mathrm{Fum}^{+}$; $\mathrm{M}^{+}, \mathrm{Mel}^{+} ; \mathrm{A}^{\mathrm{R}}, \mathrm{Amp}^{\mathrm{R}} ; \mathrm{T}^{\mathrm{R}}, \mathrm{Tet}^{\mathrm{R}}$. The bacterial DNA is denoted by open bars, the vector by thick lines, and sufficient vector restriction sites are indicated to define its relative orientation. The locations and polarities of specific genes are indicated. A scale $(1$ division $=1 \mathrm{~kb})$ is included in the map and the restriction sites are abbreviated as follows: A, AvaI ; B, BamHI; Bc, BclI; Bg, BglII; H, HindIII; Hp, HpaI; P, PstI; Pv, PvuI; R, EcoRI; Sp, SphI.

It is interesting that the smaller plasmids induce a more vigorous $\mathrm{Fum}^{+}$phenotype in the fum $\mathrm{A} I$ host. This presumably reflects the copy-dependent complementation of fum $A l$ by fumB $B^{+}$and the inverse relationship between plasmid size and copy number. The smaller plasmids also improve the rate and extent of growth on the permissive substrate, malate, for unknown reasons.

Using the maxicell procedure to detect the polypeptides expressed by different plasmids, it was clear that one component $(61 \mathrm{kDal})$ is specifically associated with the fumB gene (Fig. 4). This is the left orientated product that has the same mobility as the $1647 \mathrm{bp}$-encoded fumA gene product (Guest \& Roberts, 1983; Miles \& Guest, 1984a). The $56 \mathrm{kDal}$ product appeared to be encoded to the left of the fumB gene, and no other products or meaningful deletion or fusion products were detected in these experiments.

\section{Chromosomal location of the fum $B$ gene}

Because there are no fumB mutants, and because such mutants are unlikely to have a Fum ${ }^{-}$ phenotype (or any other easily predicted phenotype), the conventional methods of gene mapping were excluded. However, this difficulty was circumvented by strategies that rely on DNA homology to direct the insertion of the cloned $f u m B$ gene into the fumB region of the chromosome along with recognizable markers provided by the phage or plasmid vectors.

Mapping by zygotic induction. Zygotic induction occurs when an integrated prophage of a donor strain is transferred to the repressor-free cytoplasm of a non-immune recipient, and the approximate position of a prophage can be estimated from the onset of phage production in interrupted mating experiments (Jacob \& Wollman, 1956). Using an integration-deficient $\lambda$ fum $B$ transducing phage $\left[\lambda \mathrm{G} 141 ; \lambda\right.$ fumB $\Delta($ att-red $\left.) \mathrm{imm}^{21}\right]$, lysogenic derivatives of three different Hfr strains (Fig. 5) were constructed by rec-mediated integration in the fumB region of the host chromosome. Interrupted matings between $\mathrm{KL} 14(\lambda \mathrm{G} 141)$ and $\mathrm{AB} 2294\left(\mathrm{~F}^{-} \lambda^{-} \lambda^{\mathrm{R}}\right)$ gave a time of prophage entry corresponding to 90-99 min on the linkage map, just clockwise of met $E$ ( $86 \mathrm{~min})$ but anticlockwise of pro $A$ (6 min). Other matings involving $\mathrm{H}(\lambda \mathrm{G} 141)$ and KL16( $\lambda$ G141) showed no sign of prophage transfer within the first $60 \mathrm{~min}$, whereas a $\lambda \mathrm{G} 140$ 


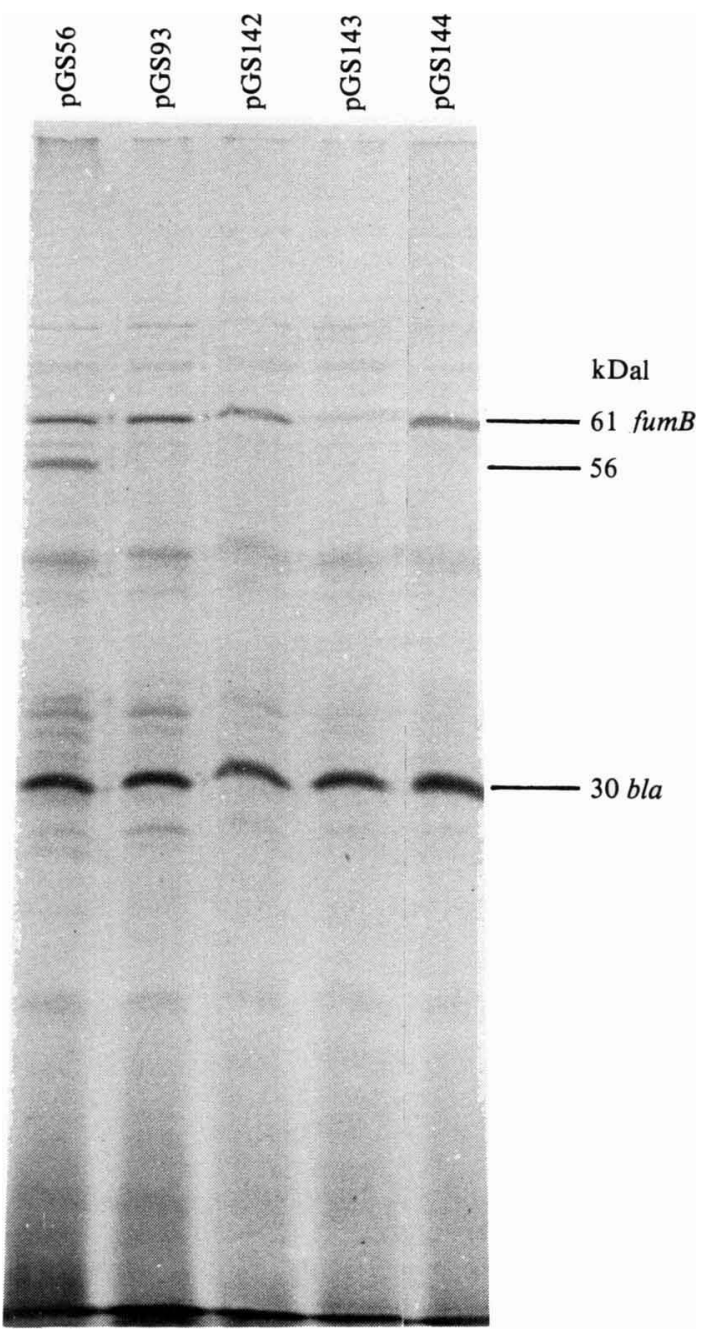

Fig. 4. Autoradiogram of ${ }^{35} \mathrm{~S}$-labelled polypeptides expressed from cloned genes. Plasmid-containing cultures were labelled for $2 \mathrm{~h}$ by the maxicell procedure. The molecular masses (kDal) of the polypeptides were deduced by reference to a set of standards.

prophage $\left(\lambda f u m B, a t t^{+}\right.$int $^{+}$red $\left.^{+}\right)$entered at a time corresponding to the primary $\lambda$ attachment site $($ att $\lambda ; 17 \mathrm{~min})$ in a control experiment with $\mathrm{H}(\lambda \mathrm{Gl} 140)$ as the lysogenic donor.

Mapping by conjugational linkage analysis. The replication of a ColE1-derived plasmid requires DNA polymerase I to be active in the transformed cells (Kingsbury \& Helinski, 1970). Consequently a plasmid such as pGS56 ( fumB $B^{+} A m p^{R}$ ) will only persist in a polA mutant if it is integrated into the chromosome. As a result an $A m p^{R}$ marker is delivered to a region of mutual homology, and can be used to locate genes that have been cloned but do not have a readily identifiable phenotype (Greener \& Hill, 1980; Silver \& Wickner, 1983). Two Hfr polA strains, CH931 (related to H) and JRG1595 (from KL14), were transformed with pGS56 and Amp ${ }^{\mathrm{R}}$ transformants were recovered, albeit at low frequencies ( $\sim 200$ per $\mu \mathrm{g}$ of plasmid DNA). These were tested for retention of the polA mutation, $\mathrm{Hfr}$ activity, and ampicillin-resistances consistent with single rather than multiple copies of the plasmid $\left(<100 \mu \mathrm{g} \mathrm{ml}^{-1}\right.$ not $>2 \mathrm{mg} \mathrm{ml}^{-1}$, respectively). One derivative of each type (CH931::pGS56 and JRG1595::pGS56) was then used for conjugation with several multiply-marked recipients: X478G3, AB2294 and JC1552. 


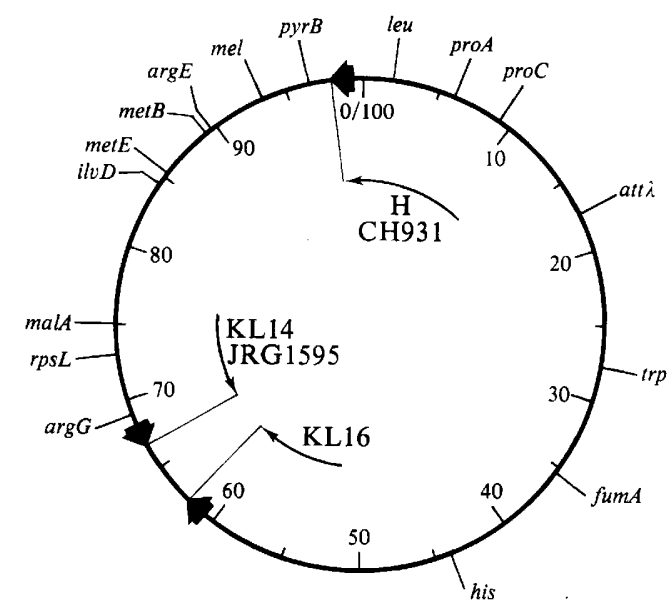

Fig. 5. Genetic map of E. coli $\mathrm{K} 12$ showing the locations of relevant markers and the points of origins of the Hfr strains.

Table 2. Transductional mapping of the integrated fumB plasmid ( $p G S 56)$

$\begin{array}{lccccc}\text { Recipient } & \text { Selection } & \begin{array}{c}\text { Transductants } \\ \text { per } 10^{6} \text { Pl kc }\end{array} & \begin{array}{c}\text { Number } \\ \text { tested }\end{array} & \begin{array}{c}\text { Amp } \\ \text { R }\end{array} \text { fumB) } & \begin{array}{c}\text { Cotransduction } \\ \text { frequency (\%) }\end{array} \\ \text { JC1552 } & \text { MetB }^{+} & 5 & 100 & 0 & <1 \\ \text { AB2495 } & \text { ArgE }^{+} & 7 & 100 & 0 & <1 \\ \text { JRG820 } & \text { Mel }^{+} & 90 & 200 & 196 & 98 \\ \text { JRG780 } & \text { FrdA }^{+} & 60 & 200 & 96 & 48 \\ \text { RM1003 } & \text { PurA }^{+} & 39 & 280 & 101 & 36 \\ \text { Q11 } & \text { Fdp }^{+} & 8 & 400 & 24 & 6 \\ \text { PA2004 } & \text { PyrB }^{+} & 14 & 300 & 3 & 1\end{array}$

The relative positions of the points of origin of the donor strains and the selective markers are shown in Fig. 5. In each case streptomycin-resistant exconjugants were selected after 100 or 120 min matings and the predictable gradients of marker transmission were obtained for nearly all the selected markers.

With the CH931 derivative the gradient was proC $\mathrm{C}^{+}>\mathrm{trp}^{+}>\mathrm{his}^{+}>\mathrm{metE}^{+}$, ilvD $\mathrm{Dleu}^{+}$and $A m p^{R}(f u m B)$, the transfer of $l e u^{+}$being unusually low for what should have been the earliest marker (Fig. 5). The coinheritance frequencies for non-selective donor markers amongst the $\operatorname{Amp}^{\mathrm{R}}($ fumB $) \operatorname{Str}^{\mathrm{R}}$ exconjugants were: leu $(40 \%) ;$ metE $(28 \%) ;$ ilvD $(25 \%)$; malA $(9 \cdot 2 \%)$; his, trp and $p r o C(<1 \%)$. These results indicate that fumB is closest to the leu marker, but the relatively high linkages with the late markers (met $E$ and $i l v D)$ suggest that it lies anticlockwise of leu and therefore close to the sex plasmid integration site. In this position the fumB plasmid could interfere with the transfer and integration of the early marker (leu), and if it is really a late marker the cotransfer with leu may be abnormally high due to F-prime activity in the donor culture.

With the KL14 derivative the gradient of marker transfer was $\arg G^{+}>\operatorname{malA}{ }^{+}>\operatorname{met} B^{+}$ $>$ leu $B^{+}$and $\operatorname{Amp}^{\mathrm{R}}($ fumB $B$, and the coinheritance frequencies of non-selective markers amongst the $\mathrm{Amp}^{\mathrm{R}}$ ( fumB $) \mathrm{Str}^{\mathrm{R}}$ exconjugants were: met $B^{+}(78 \%)$, leu $B^{+}(48 \%)$, mal $A^{+}(11 \%)$ and $\arg G^{+}(4 \%)$. These results indicate that fumB is closer to metB $(89 \mathrm{~min})$ than to leuB $(2 \mathrm{~min})$, and a detailed analysis of non-selective marker distribution in the $\mathrm{Leu}^{+} \mathrm{Str}^{\mathrm{R}}$ exconjugants confirmed that the fumB gene $\left(\mathrm{Amp}^{\mathrm{R}}\right)$ is located between these two markers. Furthermore, since fumB is not an early marker with $\mathrm{HfrH}$ derivatives, it probably lies between 89 and $97 \mathrm{~min}$.

Transduction studies. The location of the fumB gene was further investigated by transduction tests in which a P1kc lysate of CH931::pGS56 was used with a variety of recipient strains containing selectable markers in the met $B$ to $\operatorname{pyr} B(89-97 \mathrm{~min})$ region (Table 2$)$. The results show 
that the $f u m B$ gene is extremely close to the $m e l$ operon at $93.4 \mathrm{~min}$, and probably clockwise to mel because the fumB-frdA $(48 \%)$ and fumB-purA $(36 \%)$ linkages are somewhat larger than the corresponding mel-frdA (24\%) and mel-purA (4.8\%) linkages (Spencer et al., 1976). The relationship between fumB and other markers in the 93-94 min region, proP* (leuV) melA,B (bymA) phe $R^{*}$ lys $U^{*}$ cadA dgkR* aspA mopA,B ampC (Backmann, 1983; VanBogelen et al., 1983) was not investigated but it is likely that it is at least as close to mel as cadA.

\section{Relationships between fumB and neighbouring genes}

The very close proximity of the mel and $f u m B$ loci focused attention on the mel region, and it was found that two of the ColE1-fumB $B^{+}$plasmids (pGS77 and pGS78; Fig. 2) and two of the seven pBR322 derivatives (pGS56 and pGS100; Fig. 3) complemented the mel lesions of three mutants: M2508 (melA), M1900 (melB) and JRG820 (mel-1). This locates the mel genes in the $4.6 \mathrm{~kb}$ HindIII-EcoRI segment on the left of the restriction maps in Fig. 2 and 3.

It was also realized that ColEl plasmids from the Clarke-Carbon gene bank containing the mel, lys $U$ and cad genes had been identified (Tsuchiya et al., 1982; Hanatani et al., 1984; VanBogelen et al., 1983; Neidhardt et al., 1983). Furthermore, the nucleotide sequences of the mel promoter, part of the proximal melA ( $\alpha$-galactosidase) gene, and the complete melB (melibiose carrier) gene have now been defined (Shimamoto et al., 1984; Yazyu et al., 1984). The relevant ColE1-melA $A^{+} B^{+}$(pLC17-38 and pLC25-33) and ColE1-cad $A^{+}$lys $U^{+}$(pLC4-5)

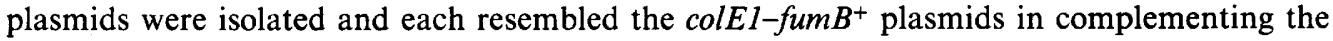
fumA 1 mutant. Their restriction patterns were identical to three of the previously-defined ColE1 plasmids: pGS77, pGS78 and pGS80, respectively (Fig. 2).

The positions of the melA and melB genes have been defined relative to the restriction map (Fig. 3) and their products have been identified as polypeptides of $50($ melA $)$ and $31 \mathrm{kDal}(\mathrm{melB})$ using the maxicell technique (Hanatani et al., 1984). The estimate for the melB product is much lower than the value of $52 \mathrm{kDal}$ derived from the nucleotide sequence, the discrepancy being attributed to the abnormally low mobility of hydrophobic proteins in SDS-polyacrylamide gels (Yazyu et al., 1984). It is very probable that the 56 (or 52) and $33 \mathrm{kDal}$ components detected previously with pGS56 and $\lambda$ fumB correspond to the $m e l A$ and $m e l B$ products.

The $m e l$ and lac operons each possess promoter-proximal galactosidase genes ( $m e l A$, lacZ), and comparable carrier protein genes ( $m e l B, l a c Y)$ that are flanked by analogous intercistronic elements, so the existence of a distal gene ( $m e l C$ ) equivalent to lac $A$ is anticipated (Yazyu $e t a l$., 1984). This would be located between the $m e l B$ and $f u m B$ genes where there is sufficient coding capacity for a polypeptide of $\leqslant 35 \mathrm{kDal}$ (Fig. 3).

The ColE1-cad $A^{+}$lys $U^{+}$plasmid (pLC4-5) encodes lysine decarboxylase ( $\left.\sim 75 \mathrm{kDal}\right)$, two forms (II and IV) of the inducible lysyl-tRNA synthetase (61 kDal; a component of the htpRcontrolled high-temperature production regulon), and one or two unidentified polypeptides ( $\sim 60$ and $62 \mathrm{kDal}$ ) (VanBogelen et al., 1983; Neidhardt et al., 1983). The fumB product may correspond to any of the latter three, although it is unlikely to be lys $U$ because only one ColE1lys $U^{+}$plasmid has been found in the Clarke-Carbon gene bank, whereas at least four different ColEl-fum $B^{+}$plasmids have been isolated. However, the structural relationships between the plasmids suggest that pLC17-38 should include at least cadA or lys $U$ (Fig. 2).

\section{Hybridization studies}

The fumA and fumB genes of $E$. coli and the citG gene of B. subtilis were examined for homology by DNA-DNA hybridization. Radioactive probes were prepared from M13 clones containing segments of the fum $A$ and $c i t G$ regions. The fumA probe included almost all of the fum $A$ gene in a 1570 nucleotide $B c l$ I segment of DNA, whereas the specificity of the cit $G$ probe was conferred by a 2700 nucleotide $S s t$ I fragment containing all of the cit $G$ gene and about half of the ger $A I$ gene (Fig. 1). In both cases radioactivity was incorporated by synthesizing the complementary strand of the single-stranded M13 vector DNA using a hybridization-probe primer (Hu \& Messing, 1982). The results of hybridization at both high and low stringencies with Southern blots of HindIII plus EcoRI digests of $\lambda$ fum $A, \lambda$ fumB and $\lambda c i t G$ DNA are shown in Fig. 6. The fum $A$ probe hybridizes to the major fum $A(3.5 \mathrm{~kb})$ and $f u m B(3.6 \mathrm{~kb})$ fragments, and 


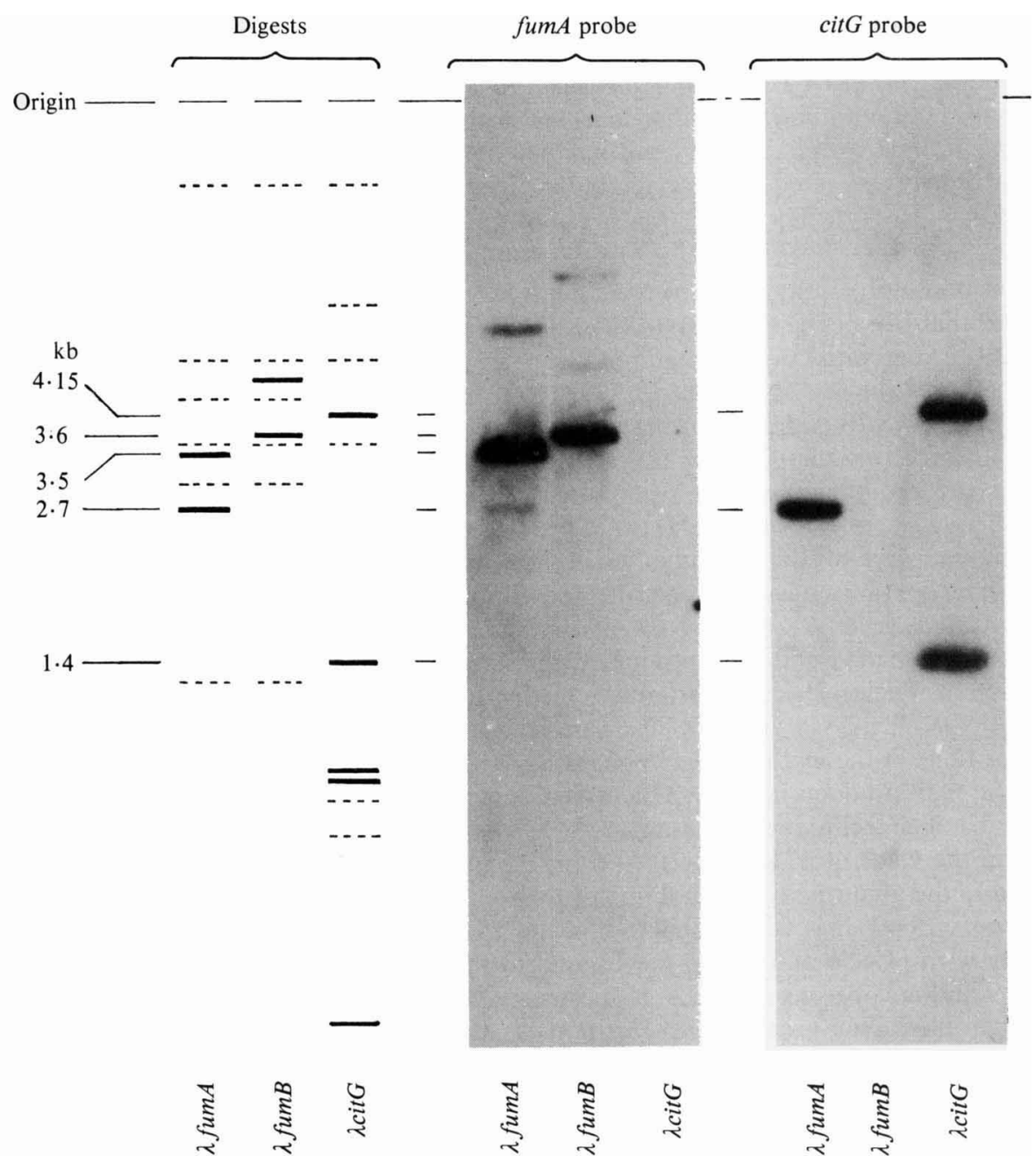

Fig. 6. Autoradiograph showing the hybridization of ${ }^{32} \mathrm{P}$-labelled fumA- and citG-containing $\mathrm{M} 13$ DNA probes (see Fig. 1) to HindIII plus EcoRI fragments of $\lambda$ fum $A$ ( $\lambda \mathrm{G} 135), \lambda$ fumB $(\lambda \mathrm{G} 139)$ and $\lambda$ citG ( $\lambda$ G142) DNA. A diagram of the restriction patterns obtained by agarose gel electrophoresis and the sizes of key fragments is included:,$--- \lambda$ vector DNA; - , bacterial DNA.

it detects some larger but minor partial digestion products. It also hybridizes weakly to the $2.7 \mathrm{~kb}$ $\lambda$ fum $A$ fragment, but not at all to $\lambda c i t G$. The citG probe hybridizes to the corresponding fragments of $\lambda c i t G$, but not to the fum $A$ - or fumB-containing fragments. However, the $c i t G$ probe does find homology in the $2.7 \mathrm{~kb}$ fragment that is adjacent to the $3.5 \mathrm{~kb}$ fum $A$ fragment in $\lambda$ fum $A$ (Fig. 6), and the hybridization persists at high stringency (not shown). These observations strongly indicate that the fum $A$ and $f u m B$ genes are homologous to each other but not to the cit $G$ gene. They also identify a region adjacent to the fum $A$ gene that is homologous to the $\operatorname{cit} G$ region but only weakly homologous to fumA. The nature of these homologies which could involve citG or $g e r A I$, and $g 48$ or some other unidentified $E$. coli gene, will be discussed later.

The same probes were used for hybridization with total DNA extracted from bacteria from several genera: Bacillus, Enterobacter, Escherichia, Proteus, Pseudomonas and Serratia. Positive results were obtained for the fumA probe with all except Bacillus and Proteus, though the $P$ seudomonas reaction was very weak. In contrast the $c i t G$ probe gave a positive reaction with all of the test organisms (data not shown). 


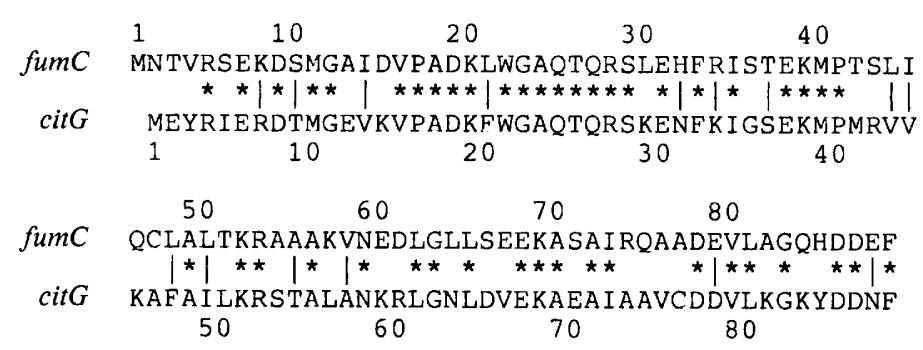

Fig. 7. Alignment of the $\mathrm{N}$-terminal sequences of the products of the putative fumarase structural genes of $E$. coli $($ fumC $=g 48)$ and $B$. subtilis $($ citG). Identical residues are indicated by asterisks and vertical bars denote conservative substitutions scoring $\geqslant 0.12$ in $\operatorname{MDM}_{78}$ (Schwartz \& Dayhoff, 1978).

\section{DISCUSSION}

The $\operatorname{fum} B$ gene is characterized by its ability to complement the fumarase deficiency conferred by the fumAl mutation, but only in multi-copy situations. Many features of the fumB gene, including its relationship with the previously-defined fum $A$ gene, have now been established as a result of studies with the cloned gene. Genetic mapping with $\lambda$ fum $B$ prophages and integrated $\operatorname{fumB}$ plasmids has located the $f u m B$ gene at $93.5 \mathrm{~min}$, very close to the $m e l$ operon, but distinct from the fumA gene at $35.5 \mathrm{~min}$. The identification of a series of ColE1 hybrid plasmids with overlapping inserts spanning the melAB-fumB-cadA region has defined the orientation of a $23.3 \mathrm{~kb}$ segment of bacterial DNA relative to the linkage map (left to right in Fig. 2 corresponds to clockwise). The $f u m B$ coding region has been located and shown to resemble the fum $A$ gene in expressing a similarly-sized product $(61 \mathrm{kDal})$ with the same anticlockwise polarity. Their mutual homology has been established in hybridization studies and this suggests that they are functionally-related genes which complement the fum $A l$ lesion by analogous mechanisms, even though fumB appears less efficient. The discovery that the $B$. subtilis fumarase gene ( $c i t G)$ is homologous with a fum $A$-linked gene ( $f u m C$ ), but not with fum $A$ or $f u m B$, increases the complexity of the situation and raises further questions concerning the functions (structural or regulatory) of the fum (and citG) genes.

Relationship between cit $G$ and $g 48$ ( fumC). The detection of good hybridization between the cit $G$ probe and the restriction fragment adjacent to fum $A$ focuses attention on a potential relationship between cit $G$ and $g 48$. The unidentified gene $(g 48)$ encodes a polypeptide of approximately the same size as the cit $G$ product. Moreover an open reading frame encoding what is presumed to be the $\mathrm{N}$-terminal segment of the $g 48$ product was defined during the sequencing of the fum $A$ gene (Miles \& Guest, 1984a). The N-terminal segments of the cit $G$ and $g 48$ products possess a remarkably high degree of homology (Fig. 7). Some $51 \%$ of the residues in the $B$. subtilis protein are retained in the $E$. coli sequence, and the homology increases to $73 \%$ when conservative substitutions scoring $\geqslant 0.12$ in the $\mathrm{MDM}_{78}$ mutation data matrix (Schwartz \& Dayhoff, 1978) are included. The same degree of homology (51\% identity) is found at the DNA level, but this is apparently not sufficient (or sufficiently extensive) to promote detectable hybridization between the $c i t G$ probe and the corresponding $3.5 \mathrm{~kb}$ fragment of $\lambda$ fumA (Fig. 6). Preliminary sequence analysis indicates that the homology with cit $G$ continues in the $g 48$ region of the $2.7 \mathrm{~kb}$ fragment, where hybridization is detected. Because the $c i t G$ gene complements fumarase mutants of $B$. subtilis and because it also directs the synthesis of fumarase in $E$. coli it is very probable that $c i t G$ is a fumarase structural gene (Moir et al., 1984). It is also likely that cit $G$ expression in $E$. coli is unaffected by any regulatory constraints that may operate on cit $G$ in $B$. subtilis, or on the corresponding gene in $E$. coli. It would therefore appear that the homologous $E$. coli gene $(g 48)$ is a fumarase structural gene (now designated fumC). This means that $E$. coli probably elaborates a fumarase that is approximately the same size as those of the Grampositive bacterium and mammalian tissue (Kobayashi \& Tuboi, 1983). 
The nature of the fumA1 mutation and the relationship between fumA and fumB. One explanation for the present results is to propose that the fumAl mutation inactivates a positive regulator or gene activator (the fum $A$ product) that is essential for the expression of the fumarase structural gene $(g 48=f u m C)$. The fum $A-f u m C$ intergenic region $(139 \mathrm{bp})$ appears to contain a rhoindependent terminator for fum $A$, a potential fum $C$ promoter, and regions of hyphenated dyad symmetry in the promoter and the segment encoding the $5^{\prime}$-end of the putative fumC transcript (Miles \& Guest, 1984a). No fumA-fumC readthrough transcript was detected, so it would appear that the genes are expressed independently. It is therefore feasible that the transcription of fum $C$ could be controlled by the fumA product, possibly by a mechanism involving a coeffector, as is observed for several positive regulators (Raibaud \& Schwartz, 1984).

According to this view the fumC gene must be tightly controlled because very little fumarase is synthesized by the fum $A^{-}$fumB $^{+}$strain (EJ1535), and attempts to generate a Fum ${ }^{+}$phenotype by constructing a pBR322 derivative containing the fum $C^{+}$gene but no other selectable marker were unsuccessful (Guest \& Roberts, 1983). It also follows from the strong homology between fum $A$ and fumB, that fumB should encode an analogous product which might only activate fum $C$ expression when amplified. Presumably it could have a higher affinity for the regulatory region of some other gene, but would function in place of fumA in the same way that elevated levels of the Trp repressor protein repress the transcription of other amino acid biosynthetic systems (Bogosian \& Somerville, 1983). The potential target of fumB regulation is unknown, but it is probably not an adjacent gene like the fum $A-f u m C$ system because the mel operon converges on fum $B$ and the putative melC gene is likely to occupy most of the space between melB and fumB. Several regulatory genes are located in the critical segment of the linkage map (e.g. bymA,phe $R$ and $d g k R$ ) but it is not known whether any of these are related to fumB (Bachmann, 1983). It is interesting that plasmid pGS54, which contains the $6.2 \mathrm{~kb}$ HindIII fumA fragment (Fig. 1), consistently generates four times as much fumarase as the EcoRI deletion-derivative (pGS57) with the smaller $3.5 \mathrm{~kb} H$ indIII-EcoRI fumA fragment (Guest \& Roberts, 1983). This could mean that the proposed structural and activator genes ( $f u m C$ and $f u m A$ ) are both amplified with pGS54, whereas the activator alone is amplified with pGS57, and fumarase production would thus be limited to the amount that could be generated from the single copy of the fumC gene in the chromosome.

Confirmation of the functions proposed for the fum genes is now being sought by several methods including the isolation of specific fumA and fumC mutants, the construction of compatible fum $A$ and fum $C$ plasmids to test for complementation in the trans situation, the isolation of fumC-lac fusions to test the prediction that fum $A$ is needed to activate fumC expression, and the isolation and enzymological characterization of the various gene products. There are other explanations for the observed results. For example the three fum genes could encode distinct structural or organizational components contributing to different fumarase activities. This would probably mean that the fumarase deficient strain (EJ1535) is a double mutant ( fum $A$ fum C). Some support for this comes from the weak hybridization between the fum $A$ probe and the fragment containing $f u m C$, which suggests that some homology may be found between fum $A$ and fum $C$ (rather than another gene in that fragment). Although they have not been excluded these and other such possibilities are at present considered plausible but less attractive. If the favoured proposals are substantiated then the fum $A$ gene will be the first example of a regulatory gene controlling the expression of a citric acid cycle enzyme.

We are very grateful for the mutant strains provided by Elliot Juni, Barbara J. Bachmann and many others, to the Medical Research Council for a research studentship (J.S.M.), and for support from the Science and Engineering Research Council.

\section{REFERENCES}

BaCHMANN, B. J. (1983). Linkage map of Escherichia coli K-12, Edition 7. Microbiological Reviews 47, 180230.
Birnboim, H. C. \& Doly, J. (1979). A rapid alkaline extraction procedure for screening recombinant plasmid DNA. Nucleic Acids Research 7, 1513-1524. 
Bogosian, G. \& Somerville, R. L. (1983). Analysis in vivo of factors affecting the control of transcription initiation at promoters containing target sites for Trp repressor. Molecular and General Genetics 191, 51-58.

Clarke, L. \& Carbon, J. (1976). A colony bank containing synthetic ColEl hybrid plasmids representative of the entire E. coli genome. Cell 9, 91-99.

Cole, S. T. \& Guest, J. R. (1980). Genetic and physical characterization of lambda transducing phages $(\lambda f r d A)$ containing the fumarate reductase gene of Escherichia coli K12. Molecular and General Genetics 178, 409-418.

Courtright, J. B. \& Henning, U. (1970). Malate dehydrogenase mutants in Escherichia coli K-12. Journal of Bacteriology 102, 722-728.

Creaghan, I. C. \& Guest, J. R. (1978). Succinate dehydrogenase-dependent nutritional requirement for succinate in mutants of Escherichia coli K12. Journal of General Microbiology 107, 1-13.

Dretzen, G., Bellard, M., Sassone-Corsi, P. \& Chambon, P. (1981). A reliable method for the recovery of DNA fragments from agarose and acrylamide gels. Analytical Biochemistry 112, 295298.

Gray, C. T., Wimpenny, J. W. T. \& Mossman, M. R. (1966). Regulation of metabolism in facultative bacteria. II. Effects of aerobiosis, anaerobiosis and nutrition on the formation of Krebs cycle enzymes in Escherichia coli. Biochimica et biophysica acta 117, 3341.

GREENER, A. \& HILl, C. W. (1980). Identification of a novel genetic element in Escherichia coli $\mathrm{K}-12$. Journal of Bacteriology 144, 312-331.

GuEST, J. R. (1981). Partial replacement of succinate dehydrogenase function by phage- and plasmidspecified fumarate reductase in Escherichia coli. Journal of General Microbiology 124, 17-23.

Guest, J. R. \& RoberTs, R. E. (1983). Cloning, mapping and expression of the fumarase gene of Escherichia coli K12. Journal of Bacteriology 153, 588-596.

Guest, J. R., Roberts, R. E. \& Stephens, P. E. (1983). Hybrid plasmids containing the pyruvate dehydrogenase complex genes and gene-DNA relationships in the 2 to 3 minute region of the Escherichia coli chromosome. Journal of General Microbiology 129, 671-680.

Hanatani, M., Yazyu, H., Shiota-NiIya, S., MoriYama, Y., Kanazana, H., Futai, M. \& TsuchiYa, T. (1984). Physical and genetic characterization of the melibiose operon and identification of the gene products in Escherichia coli. Journal of Biological Chemistry 259, 1807-1812.

Herbert, A. A. \& GUEST, J. R. (1968). Biochemical and genetic studies with lysine + methionine mutants of Escherichia coli : lipoic acid and $\alpha$-ketoglutarate dehydrogenase-less mutants. Journal of General Microbiology 53, 363-381.

Hu, N. \& Messing, J. (1982). The making of strandspecific M13 probes. Gene 17, 271-277.

JaCOB, F. \& Wollman, E. L. (1956). Sur les processus de conjugaison et de recombinasion génétique chez $E$. coli. I. L'induction par conjugaison ou induction zygotique. Annales de l'Institut Pasteur 91, 486-510.

KingSBURY, D. T. \& HelinsKi, D. R. (1970). DNA polymerase as a requirement for the maintenance of the bacterial plasmid colicinogenic factor E1. Biochemical and Biophysical Research Communications 41, 1538-1544.

KoBAYASHI, K. \& TUBOI, S. (1983). End group analysis of the cytosolic and mitochondrial fumarases from rat liver. Journal of Biochemistry 94, 707-713.

LAMBden, P. R. \& Guest, J. R. (1976). Mutants of Escherichia coli $\mathrm{K} 12$ unable to use fumarate as an anaerobic electron acceptor. Journal of General Microbiology 97, 145-160.

LeDERBERG, E. M. \& CoHEN, S. N. (1974). Transformation of Salmonella typhimurium by plasmid deoxyribonucleic acid. Journal of Bacteriology 119 , 1072-1074.

Maniatis, T., Fritsch, E. F. \& SambrooK, J. (1982). Molecular Cloning: a Laboratory Manual. Cold Spring Harbor, NY: Cold Spring Harbor Laboratory.

Miles, J. S. \& Guest, J. R. (1984a). Complete nucleotide sequence of the fumarase gene, fum $A$, of Escherichia coli. Nucleic Acids Research 12, 36313642.

Miles, J. S. \& Guest, J. R. (1984b). Nucleotide sequence and transcriptional start point of the phosphomannose isomerase gene $(\operatorname{man} A)$ of Escherichia coli. Gene 32, 41-48.

Miles, J. S. \& Guest, J. R. (1985). Complete nucleotide sequence of the fumarase gene (citG) of Bacillus subtilis 168. Nucleic Acids Research 13, 131-140.

MoIR, A., Feavers, I. M. \& Guest, J. R. (1984). Characterization of the fumarase gene of Bacillus subtilis 168 cloned and expressed in Escherichia coli K12. Journal of General Microbiology 130, 3009 . 3017.

Neidhardt, F. C., Vaughn, V., Phillips, T. A. \& BLOCH, P. L. (1983). Gene-protein index of Escherichia coli K-12. Microbiological Reviews 47, 231-284.

RaIBaUd, O. \& SChWARTZ, M. (1984). Positive control of transcription initiation in bacteria. Annual Review of Genetics 18, 173-206.

SANCAR, A., HACK, A. M. \& RUPP, W. D. (1979). Simple method for identification of plasmid-coded proteins. Journal of Bacteriology 137, 629-693.

Sanger, F., Coulson, A. R., Barrell, B. G., Smith, A. J. H. \& RoE, B. A. (1980). Cloning in singlestranded bacteriophage as an aid to rapid DNA sequencing. Journal of Molecular Biology 143, 161178.

SchwartZ, R. M. \& Dayhoff, M. O. (1978). Matrices for detecting distant relationships. In Atlas of Protein Sequence and Structure, vol. 5. (supplement 3), pp. 353-358. Edited by M. O. Dayhoff. Washington, DC: National Biomedical Research Foundation.

Shaw, D. J. \& GuEST, J. R. (1982). Amplification and product identification of the finr gene of Escherichia coli. Journal of General Microbiology 128, 2221-2228.

Shimamoto, T., Yazyu, H., Futai, M. \& Tsuchiya, T. (1984). Nucleotide sequence of the promoter region of the melibiose operon of Escherichia coli. Biochemical and Biophysical Research Communications 121, 41-46.

SILVER, P. \& WICKNER, W. (1983). Genetic mapping of the Escherichia coli leader (signal) peptidase gene (lep): a new approach for determining the map position of a cloned gene. Journal of Bacteriology 154, $569-572$. 
Smith, M. W. \& Neidhardt, F. C. (1983). Proteins induced by anaerobiosis in Escherichia coli. Journal of Bacteriology 154, 336-343.

SOUTHERN, E. (1975). Detection of specific sequences among DNA fragments separated by gel electrophoresis. Journal of Molecular Biology 98, 503-518.

SPENCER, M. E. \& Guest, J. R. (1973). Isolation and properties of fumarate reductase mutants of Escherichia coli. Journal of Bacteriology 114, 563-570.

SPencer, M. E., Lebeter, V. M. \& GUest, J. R. (1976). Location of the aspartase gene $(\operatorname{asp} A)$ on the linkage map of Escherichia coli K12. Journal of General Microbiology 97, 73-82.

Tsuchiya, T., OtTina, K., Moriyama, Y., Newman, M. J. \& WILSON, T. H. (1982). Solubilization and reconstitution of the melibiose carrier from a plasmid-carrying strain of Escherichia coli. Journal of Biological Chemistry 257, 5125-5128.

Vanbogelen, R. A., Vaughn, V.\& Neidhardt, F. C. (1983). Gene for heat-inducible lysyl-tRNA synthetase $($ lys $U)$ maps near cadA in Escherichia coli. Journal of Bacteriology 153, 1066-1068.

VOGEL, H. \& BONNER, D. M. (1956). A convenient growth medium for $E$. coli and some other microorganisms. Microbial Genetics Bulletin 13, 43-44.

YazyU, H., Shiota-Nirya, S., Shimamoto, T., Kanazawa, H., Futai, M. \& Suchiya, T. (1984). Nucleotide sequence of the $m e l B$ gene and characteristics of deduced amino acid sequence of the melibiose carrier in Escherichia coli. Journal of Biological Chemistry 259, 4320-4326. 